\title{
Insect feeding preferences on Piperaceae species observed in São Paulo city, Brazil
}

\author{
Sérgio A. Vanin ${ }^{1 *}$, Clécio S. Ramos², Elsie F. Guimarães ${ }^{3} \&$ Massuo J. Kato $^{2}$
}

${ }^{1}$ Museu de Zoologia and Instituto de Biociências, Universidade de São Paulo, Caixa Postal 26077, 05513-970 São Paulo-SP, Brazil. savanin@ib.usp.br

${ }^{2}$ Instituto de Química, Universidade de São Paulo, Caixa Postal 26077, 05513-970 São Paulo-SP, Brazil. majokato@iq.usp.br

${ }^{3}$ Instituto de Pesquisas Jardim Botânico do Rio de Janeiro, Rua Jardim Botânico, 1008, 22460-070 Rio de Janeiro-RJ, Brazil.

\begin{abstract}
Insect feeding preferences on Piperaceae species observed in São Paulo city, Brazil. Piperaceae species have been placed among the basal angiosperm and are adapted to a variety of habitats including moist forests, secondary vegetation and dry high lands. The major anatomical/morphology features are of small trees, vines, and shrubs for Piper species, while the epiphytic and succulent characteristics are predominant forms among Peperomia species. Their secondary chemistry can be mostly represented by amides, phenylpropanoids/lignoids, and chromenes in addition to a phletoria of biosynthetically mixed-origin secondary compounds. Although several amides and lignans are known as insecticides, several phytophagous insects, among which some considered pests of economic importance, have been observed feeding vigorously on Piperaceae species. Herein we describe the feeding preferences of fourteen phytophagous species of Coleoptera, Lepidoptera and Hemiptera over approximately fifty Piperaceae species observed in São Paulo, SP, Brazil, in a long-term basis.
\end{abstract}

KEYWORDS. Host plant; Insect-plant interaction; Piper; secondary metabolites.

RESUMO. Preferências alimentares de insetos por espécies de Piperaceae, observadas na cidade de São Paulo, Brasil. As espécies de Piperaceae têm sido posicionadas entre as angiospermas basais e são frequentemente encontradas em habitats diversificados que incluem matas ciliares, vegetação secundária e campos rupestres. As espécies de Piper possuem hábitos de plantas herbáceas, arboretos e trepadeiras enquanto que, no caso de Peperomia, é freqüente o hábito de epífitas e suculentas. As classes de metabólitos secundários que caracterizam espécies de Piperaceae são amidas, fenilpropanóides/ lignóides e cromenos, além de diversos outros de origem biossintética mista de menor representatividade. Apesar de muitos desses possuírem atividades inseticidas, diversos insetos fitófagos, alguns considerados pragas de importância econômica, foram observados alimentando-se de espécies de Piperaceae. Neste trabalho são relatadas as preferências alimentares de quatorze espécies fitófagas de Coleoptera, Lepidoptera e Hemiptera sobre aproximadamente cinqüenta espécies de Piperaceae observadas em São Paulo, SP, Brasil, durante um período de quatro anos.

PALAVRAS-CHAVE. Interações planta-inseto; metabólitos secundários; Piper; planta hospedeira.

Among the extraordinary diversity found within the order Insecta, representing nearly $60 \%$ of the biota on Earth, $46 \%$ have developed herbivorous habits during the evolutionary process (Cronin \& Abrahamson, 2001). The successful coadaptation between insects and plants was an evolutionary event that provided important advantages to plants especially when pollinization and seed dispersal are concerned. In addition to volatile attractants in flowers and fruits, secondary compounds in leaves also have assumed crucial importance in the life cycle of insects acting as juvenile and moulting hormones for their normal growth and developmental process (Harborne, 2001). Nevertheless, some of the plant secondary compounds act as potent toxins and limit the generalized herbivory posing severe restrictions to the insects to cope with and as a consequence the majority of herbivorous insects are adapted to a relatively limited number of plant species (Glendinning et al. 2002; Ward et al. 2003). Among the mechanism developed by insects to overcome such toxicity, the digestive process appeared to be the simplest and efficient process in which several degradation reactions takes place. Additionally, insects are capable to sequester and use them for their own defense against pathogens and predators or as pheromones (Nishida, 2002; Hartmann et al. 2005). Secondary compounds are also involved in the mediation process of the third trophic level in which parasitoids interact with host insects (Abrahanson \& Weiss, 1997). Indeed, the concept of adaptation role for secondary metabolites under ecological and evolutionary approach between insects and plants is broadly accepted and almost all interaction has at some point involvement of secondary compounds (Fordyce \& Agrawal, 2001; Harborne, 2001).

A detailed investigation of insect-plant interactions is required in order to reconstruct the evolutionary path and such approach should involve determination of behavior, major phytochemicals, and phylogenetic aspects (Becerra, 1997). Then, the first step to clarify such relationship is the identification of host plants and their phytophagous insects in natural habitats.

Piperaceae. The family Piperaceae together with the family Chlorantaceae have been considered as basal Angiospermae (Jaramillo et al. 2004). The genus Piper is the largest one, 
comprising more than 700 species (Parmar, 1997). Approximately 240 species of Piper L., 25 species of Ottonia Sprengel and two species of Pothomorphe Miquel have been described in Brazil (Yuncker, 1973, 1975).

Several Piperaceae species have been used in the medicine. In Jamaica, of the eleven known species, $P$. aduncum L. and $P$. hispidum $\mathrm{Sw}$. are mentioned as medicinal for stomachaches and as insect repellents (Asprey \& Thornton, 1954). The seeds of black pepper, P. nigrum L., originally from the African east, have worldwide use as seasoning, while their leaves, roots and seeds are used in the treatment of bronchitis, gastrointestinal diseases, venereal diseases and rheumatism.

The phytochemical investigations of Piperaceae species have shown the accumulation of several insecticidal compounds in $P$. nigrum L., P. betle L., P. spirei C. DC., $P$. decurrens C. DC. and P. longun L. (Park et al. 2002; Navickiene et al. 2000; Paula et al. 2000; Parmar et al. 1997; Chauret et al. 1996). On the other hand several insect species have been described as visitors/phytophagous/pollinators (Figueiredo \& Sazima, 2000).

Only recently, the chemical ecology of Piper species has been addressed (Dyer et al. 2004) in which the hypothesis of ecological trade-offs in defenses was examined in Piper cenocladum C. DC. regarding its relationship with ants.

The major aim of this paper is to describe the investigations carried out during four years in which feeding preferences of fourteen insect species on over fifty Piperaceae species were observed. The study was addressed to record possible specificity preferences of Coleptera, Lepidoptera and Hemiptera on Piperaceae species.

\section{MATERIALAND METHODS}

Study site. The study was performed between August 2000 and January 2004 at an experimental field (garden next to the Laboratory of Natural Product Chemistry - LNP, S $23^{\circ} 33^{\prime} 915^{\prime \prime}$; W $46^{\circ} 43^{\prime} 671^{\prime \prime}$ ) of the Institute of Chemistry of the Universidade de São Paulo and on the reserve (CUASO) at the Campus of the Universidade de São Paulo (São Paulo, SP, Brazil).

Insect species. The insect species were collected mostly at the experimental field and also in different sites in Brazil and were identified by the first author (SAV) and Drs. Cleide Costa (Museu de Zoologia, Universidade de São Paulo), Sergio Ide (Instituto Biológico de São Paulo), and Gustavo Accacio (Departamento de Zoologia, Instituto de Biociências, Universidade de São Paulo). Vouchers specimens (Table 1) are deposited in the Museu de Zoologia, USP (Brazil).

The feeding preference of insect species was determined by field and laboratory observations. The insect species reared in laboratory were maintained in cages for a month with diet consisting of leaves of Piperaceae under artificial light $(17 \mathrm{~h}$ light - $7 \mathrm{~h}$ dark) and room temperature $\left(24\right.$ to $\left.27^{\circ} \mathrm{C}\right)$.

Plant Materials. Out of fifty Piperaceae species cultivated at LNP only $P$. gaudichaudianu Kunth, $P$. regnellii C. DC. and Pothomorphe umbellata (L.) Miq. were originally found in this area. Moreover, additional species in this site include Virola sebifera Aubl. and V. oleifera (Schott) A.C. Smith (Myristicaceae); Araucaria angustifolia (Bentol.) Kuntze (Araucariaceae); Psidium guayava L. (Myrtaceae); Theobroma cacao L. (Sterculiaceae) and Cecropia spp. (Cecropiaceae).

The leaves from Piperaceae species were collected in the Campus of the Universidade de São Paulo (Brazil) in December 2000 and were identified by Dr. Elsie F. Guimarães (Jardim Botânico do Rio de Janeiro - Brazil). A voucher specimen (Piper callosum C. DC, Kato-0175; Piper solmsianum C.DC, Kato0369; Piper richardiaefolium Kunth, KATO-0290; Piper arboreum Yunck, KATO-0007; Piper hispidum Sw, KATO0014; Piper gaudichaudianum Kunth, KATO-0031; Piper aduncum L., KATO-0077; Piper crassinervium Kunth, KATO0091; Peperomia urocarpa Fisch. \& Mey., KATO-0104; Piper amalago var. medium (Jacq.) Yunck, KATO-0110; Piper hoffmannseggianum Roem. \& Schult., KATO-0127; Piper macedoi Yunck, KATO-0136; Piper cernuum Kunth, KATO137; Piper nigrum L., KATO-0157; Peperomia galioides Humb., Bonpl. \& Kunth, KATO-0168; Piper tuberculatum Jacq, KATO-0169; Ottonia martiana Miq., KATO-172; Ottonia propinqua Kunth, KATO-0177; Piper macedoi Yunck., KATO0180; Piper hemmendorffi C. DC., KATO-0181; Piper glabratum Kunth, KATO-0185; Piper tectoniifolium Kunth, KATO-0192; Piper chimonanthifolium Kunth; KATO-0193; Piper cubataonum C. DC., KATO-0194; Piper dilatatum Rich., KATO-0195; Piper schenckii C. DC., KATO-0202; Piper pseudopothifolium C. DC., KATO-0211; Peperomia oreophila Hensch., KATO-0224; Piper lhotzkyanum Kunth, KATO-0226; Pothomorphe peltata (L.) Miq., KATO-0235; Piper rivinoides Kunth, KATO-0254; Piper permucronatum Yunck., KATO0283; Peperomia rupestris Humb., Bompl. \& Kunth, KATO0284; Peperomia arifolia Miq., KATO-0285; Piper xylosteoides (Kunth) Steud., KATO-0289; Peperomia alata Ruiz \& Pav., KATO-0291; Peperomia glabella var. nervulosa (C. DC.) Yunck., KATO-0293; Peperomia serpens (Sw.) Loud., KATO-0295; Peperomia rotundifolia (L.) Humb., Bompl. \& Kunth, KATO-0300; Peperomia circinnata Link, KATO-0312; Peperomia elongata Kunth, KATO-0313; Peperomia pereskiaefolia (Jacq.) Humb., Bonpl. \& Kunth, KATO-0314; Peperomia betle L., KATO-0333; and Peperomia blanda (Jacq.) Humb., Bonpl. \& Kunth, KATO-0354; are deposited at the Herbarium of Instituto de Pesquisas Jardim Botânico do Rio de Janeiro; P. regnellii C. DC., Benevides S/n.SPF112.6.84, is deposited at the Herbarium of Instituto de Biociências da Universidade de São Paulo.

\section{RESULTS ANDDISCUSSION}

During the first year most of the effort was to determine the feeding preferences for fourteen species of insects collected and to identify them and the respective host plants. The feeding mechanisms observed varied from chewing, 

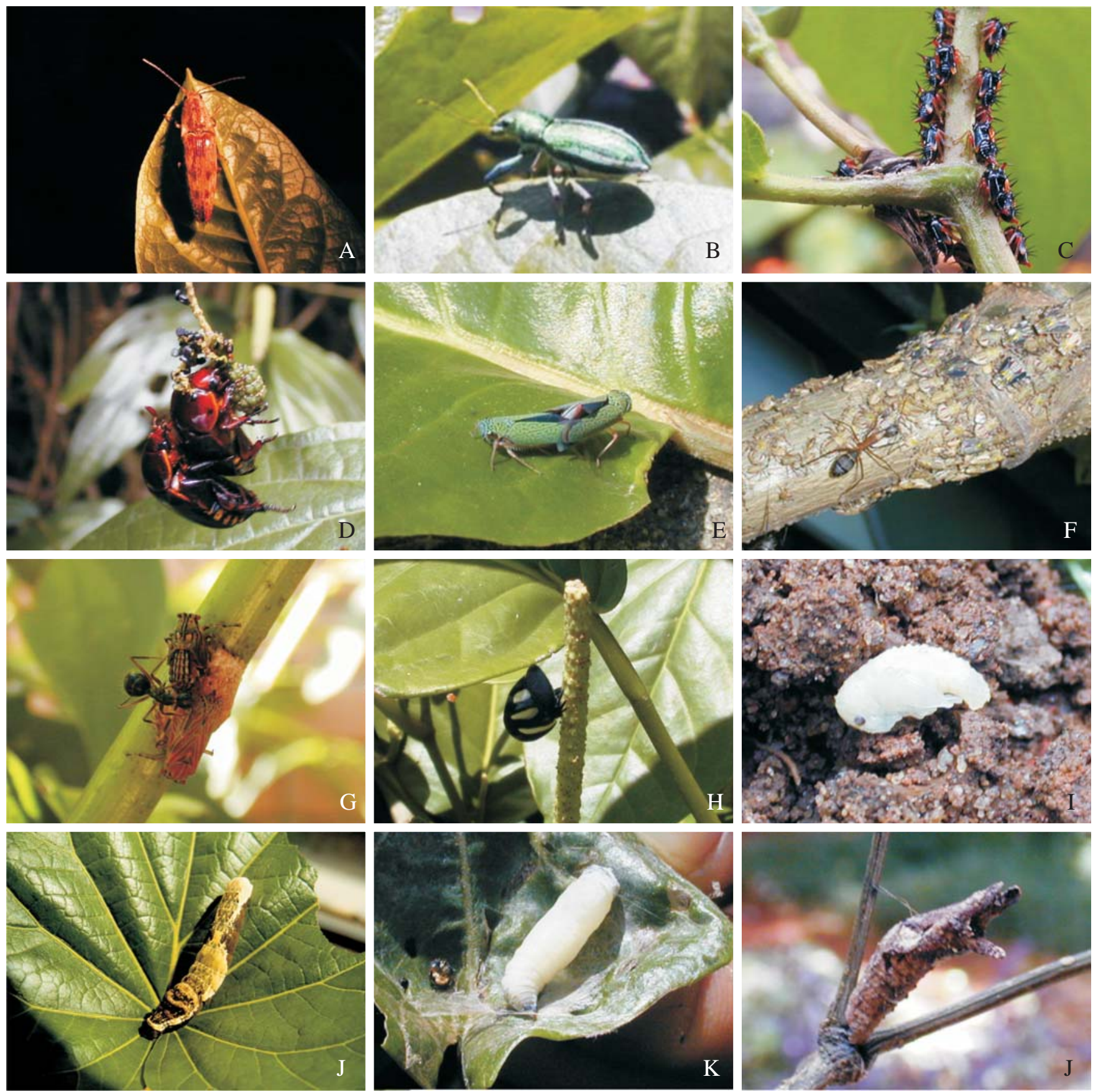

Fig. 1. Phytophagous insects associated to Piper species. The ecological aspects of each species are reported on the text. A, adult of Conoderus fuscofasciatus on leaf of Piper solmsianum; B, adult of Naupactus bipes on leaf of P. gaudichaudianum; C, nymphs of Callocanophora sp. on stem of $P$. aduncum; D, adults of Chasmodia sp. on fruit of $P$. gaudichaudianum; E, couple of Sibovia sagata on leaf of $P$. regnellii; F, nymphs of Aethalium reticulatum attended by ants on stem of $P$. aduncum; $\mathrm{G}$, same as in $\mathrm{F}$, but female adult protecting cluster of eggs; $\mathrm{H}$, adult of Membracis foliata on fruit of $P$. arboreum; I, pupa of $N$. bipes collected on roots of P. gaudichaudianum; J, caterpillar of Heraclides brasiliensis on leaf of P. solmsianum; K, pupa of Quadrus u-lucida on leaf of P. regnellii, and $\mathrm{L}$, pupa of Heraclides hectorides on stem of $P$. solmsianum.

sucking and piercing according to the insect order (Table 2). Next, the major classes of secondary metabolites accumulated in each Piperaceae species has been examined based on previous phytochemical investigations carried out by our group. The occurrence of amides, lignans, neolignans, prenylated benzoic acid, chromene, phenylpropanoids, terpenoids, pyrones, flavones and chalcones have been reported (Alécio et al. 1998; Benevides et al. 1999; Baldoqui et al. 1999; Navickiene et al. 2000; Martins et al. 2000; Martins et al. 2003; Lago et al. 2004; Kitamura et al. 2006; Kato \& Furlan, 2007).

Feeding preferences of Coleoptera species. The preliminary field observations revealed the presence of the 
weevil Naupactus bipes in four adult specimens of Piper gaudichaudianum Kunth in which about seventy adults have been observed. However, some individuals were also observed feeding on leaves of $P$. arboreum var. hirtellum Yuck, $P$. aduncum L., P. hispidum $\mathrm{Sw}$. and $P$. regnellii C. DC.

The specificity of feeding habit of beetle was further investigated by means of multiple-choice tests under laboratory conditions. Ten specimens of $N$. bipes were maintained in a cage containing fresh leaves of Piper hispidum Sw., $P$. arboreum var. hirtellum Yunk, $P$. gaudichaudianum Kunth, P. aduncum L. and P. regnellii C. DC. during the period of one week. After two days leaves of $P$. gaudichaudianum Kunth were significantly (about 30\% of leaf area) eaten by the beetles. Next, when the leaves of $P$. gaudichaudianum were removed, the beetles started to feed only on $P$. regnellii C. DC. Finally, when the leaves of $P$. regnellii C. DC. were removed the beetles stopped to eat during the following four days.

During the following generations, we found several larvae $N$. bipes in the roots of $P$ gaudichaudianum Kunth and $P$. regnellii $\mathrm{C}$. DC. These results associated to the feeding behavior of adults on leaves of Piper species indicated that the beetle species have a narrow relationship with these plant species.

The life cycle of $N$. bipes is annual and the presence of adult beetles coincides with the fructification period of $P$. gaudichaudianum Kunth from September to January. Its feeding preference under field conditions has remained precisely the same during the four generations. Although some beetle species such as $N$. bipes, $N$. basilicus and $N$. versatilis are considered polyphagous pests (Nora \& Reis Filho, 1989; Reis Filho \& Nora, 1988) they revealed a clear feeding preference for prenylated benzoic acid accumulating Piper species (Table 2).

The weevils $N$. basilicus (Germar, 1824) and $N$. versatilis (Hustache, 1947) had feeding preference by $P$. gaudichaudianum Kunth in which adults and larvae were also observed on the leaves and roots, respectively.

Individual male and female leaf chafer Chasmodia sp. were observed on fruits of $P$. gaudichaudianum Kunth during its mating. Larvae of Conoderus spp. are soil-dwelling that feed on small roots and bore into underground portions of stem causing plants to wither and die but virtually no information regarding the food preferences for adults is available. Apparently they cause minor damage by feeding on tender plant tissues, such as leaves and flower buds (Lawrence, 1991; Lima, 1953).

Feeding preferences of Lepidoptera species. The caterpillars of $H$. hectorides (Esper, 1794), H. brasiliensis (Rothsch \& Jord, 1906) and Q. u-lucida (Plötz, 1884) feeding on leaves from Piper spp. appeared naturally at the experimental site. The three species showed a narrow chemical specificity by leaves from Piper species accumulating lignans or neolignans (Table 2). The caterpillars of $Q$. u-lucida were observed feeding on leaves from $P$. regnellii C. DC. $(N=40)$, P. solmsianum C. DC. $(N=15)$, P. callosum C. DC. $(N=3)$ and
Table I. Species of insects observed feeding on Piperaceae species.

\begin{tabular}{|c|c|}
\hline $\begin{array}{c}\text { Code } \\
\text { species }\end{array}$ & Insects species \\
\hline CSR001 & $\begin{array}{l}\text { 1. Naupactus bipes (Germar, 1824), Coleoptera - } \\
\text { Curculionidae }\end{array}$ \\
\hline CSR002 & $\begin{array}{l}\text { 2. Naupactus basilicus (Germar, 1824), Coleoptera - } \\
\text { Curculionidae }\end{array}$ \\
\hline CSR003 & $\begin{array}{l}\text { 3. Naupactus versatilis (Hustache, 1947), Coleoptera - } \\
\text { Curculionidae }\end{array}$ \\
\hline CSR004 & 4. Chasmodia sp., Coleoptera - Scarabaeidae \\
\hline CSR005 & $\begin{array}{l}\text { 5. Quadrus u-lucida (Plötz, 1884), Lepidoptera - } \\
\text { Hesperiidae }\end{array}$ \\
\hline CSR006 & $\begin{array}{l}\text { 6. Heraclides hectorides (Esper, 1794), Lepidoptera - } \\
\text { Papilionidae }\end{array}$ \\
\hline CSR007 & $\begin{array}{l}\text { 7. Heraclides brasiliensis (Rothsch \& Jord, 1906), } \\
\text { Lepidoptera -Papilionidae }\end{array}$ \\
\hline CSR008 & $\begin{array}{l}\text { 8. Conoderus fuscofasciatus (Eschscholtz, 1829), } \\
\text { Coleoptera - Elateridae }\end{array}$ \\
\hline CSR009 & $\begin{array}{l}\text { 9. Edessa meditabunda (Fabricius, 1794), Hemiptera - } \\
\text { Pentatomidae }\end{array}$ \\
\hline CSR010 & $\begin{array}{l}\text { 10. Membracis foliata L., } 1767 \text {, Hemiptera - } \\
\text { Membracidae }\end{array}$ \\
\hline CSR011 & $\begin{array}{l}\text { 11. Sibovia sagata (Sigworet, 1859), Hemiptera - } \\
\text { Cicadellidae }\end{array}$ \\
\hline CSR012 & 12. Callocanophora sp., Hemiptera - Membracidae \\
\hline CSR013 & $\begin{array}{l}\text { 13. Aethalion reticulatum (L., 1767), Hemiptera - } \\
\text { Aethalionidae }\end{array}$ \\
\hline CSR014 & $\begin{array}{l}\text { 14. Sibaria armata (Dallas, 1851), Hemiptera - } \\
\text { Pentatomidae }\end{array}$ \\
\hline
\end{tabular}

P. richardiaefolium Kunth $(N=4)$. The main host is $P$. regnellii C. DC. with caterpillars, pupae and oviposition by adult on leaves occurring throughout the year, except during July and August. The caterpillars of $H$. hectorides were observed feeding on leaves of $P$. regnellii C. DC. $(N=6)$ and $P$. solmsianum C. DC. $(N=3)$, while the caterpillars of $H$. brasiliensis were observed feeding only on leaves of $P$. regnellii C. DC. $(N=7)$.

The caterpillars feeding on leaves from Piper species were also observed in other sites. The H. hectorides $(N=4)$ and $Q$. u-lucida $(N=3)$ on $P$. solmsianum C. DC. (Ubatuba - SP, Brazil, S 2327'731' W 45'11'760'), $H$. hectorides on $P$. solmsianum C. DC. $(N=4)$ (Poços de Caldas, MG, Brazil, S 21 '58'300' 'W 46²2'296"), H. hectorides on $P$. solmsianum $\mathrm{C}$. DC. $(N=4)$ and P. regnellii C. DC. $(N=3)$ (São Paulo, SP, Brazil, S 233' $906^{\circ}$ "WO 46 $43^{\circ}$ '634") and H. hectorides on Piper sp. $(N=9)$ (Itabuna, BA, Brazil).

Larvae of $H$. brasiliensis have been observed feeding on many species of Piperaceae (Tyler et al., 1994), but can be also found on Rutaceae including cultivated Citrus spp; larvae of $H$. hectorides was reported feeding on Piper amalago L. but rarely on Rutaceae; larvae of $Q$. u-lucida feed on Piper spp., forming shelters by folding a single leave of the host and tying it with silk.

Feeding preference species of Hemiptera. The feeding 
Table II. Relationship between insects and Piperaceae species and their major secondary metabolites.

\begin{tabular}{|c|c|c|c|c|c|c|c|}
\hline Insect & Adult & Nymph & Larvae & $\begin{array}{c}\text { Feeding } \\
\text { Mechanisms }\end{array}$ & Piperaceae & $\begin{array}{c}\text { Plant Secondary } \\
\text { metabolites }\end{array}$ & References \\
\hline \multirow[t]{5}{*}{ Naupactus bipes } & leaves & & root & chewing & P. gaudichaudianum & $\mathrm{PBA}^{\mathrm{a}}$ & Lago et al. 2004. \\
\hline & leaves & & root & & P. regnellii & $\mathrm{BF}^{\mathrm{b}}$ Neolignans & Benevides et al. 1999. \\
\hline & leaves & & root & & P. aduncum & PBA & Baldoqui et al. 1999. \\
\hline & leaves & & root & & P. hispidum & PBA & unpublished $^{\mathrm{d}}$ \\
\hline & leaves & & root & & P. arboreum & PBA & unpublished \\
\hline N. basilicus & leaves & & root & chewing & P. gaudichaudianum & PBA & Lago et al. 2004. \\
\hline N. versatilis & leaves & & root & chewing & P. gaudichaudianum & PBA & Lago et al. 2004. \\
\hline $\begin{array}{l}\text { Chasmodia sp. } \\
\text { Conoderus }\end{array}$ & fruit & & root & chewing & P. gaudichaudianum & PBA & Lago et al. 2004. \\
\hline fuscofasciatus & leaves & & & chewing & P. solmsianum & $\mathrm{THF}^{\mathrm{c}}$ Lignans & Martins et al. 2000. \\
\hline \multirow[t]{5}{*}{ Quadrus u-lucida } & & & leaves & chewing & P. solmsianum & THF Lignans & Martins et al. 2000. \\
\hline & & & leaves & & P. richadiaefolium & $\mathrm{FF}^{\mathrm{d}}$ Lignans & Unpublished \\
\hline & & & leaves & & Piper sp. & Lignans & unpublished \\
\hline & & & leaves & & P. regnellii & BF Neolignans & unpublished \\
\hline & & & leaves & & P. callosum & Lignans & unpublished \\
\hline \multirow[t]{2}{*}{ Heraclides hectorides } & & & leaves & chewing & P. regnellii & BF Neolignans & Benevides et al. 1999. \\
\hline & & & leaves & & P. solmsianum & THF Lignans & unpublished \\
\hline H.brasiliensis & & & leaves & chewing & P. regnellii & BF Neolignans & Benevides et al. 1999. \\
\hline \multirow[t]{2}{*}{ Membracis foliata } & stem & stem & & piercing and sucking & P. arboreum & PBA & unpublished \\
\hline & stem & stem & & & P. aduncum & PBA & Baldoqui et al. 1999. \\
\hline Sibovia sagata & leaves & & & piercing and sucking & P. solmsianum & THF Lignans & Martins et al. 2000. \\
\hline Edessa meditabunda & leaves & & & piercing and sucking & P. solmsianum & THF Lignans & Martins et al. 2000. \\
\hline \multirow{4}{*}{$\begin{array}{l}\text { Aethalium reticulatum } \\
\text { Callocanophora } \mathrm{sp} .\end{array}$} & stem & stem & & piercing and sucking & P. tuberculatum & Amides & Navickiene et al. 2000. \\
\hline & stem & stem & & piercing and sucking & P. gaudichaudianum & PBA & Lago et al. 2004. \\
\hline & stem & stem & & & P. arboreum & PBA & unpublished \\
\hline & stem & stem & & & P. aduncum & PBA & Baldoqui et al. 1999. \\
\hline \multirow[t]{4}{*}{ Sibaria armata } & fruit & fruit & & piercing and sucking & P. aduncum & PBA & Baldoqui et al. 1999. \\
\hline & fruit & fruit & & & P. hispidum & PBA & unpublished \\
\hline & fruit & fruit & & & P. arboreum & PBA & unpublished \\
\hline & fruit & fruit & & & P. cernuum & $\begin{array}{l}\text { Dihydrocinnamic } \\
\text { acids and lignans }\end{array}$ & Danellute et al. 2005. \\
\hline
\end{tabular}

a: Prenylated benzoic acids; ${ }^{\mathrm{b}}$ : benzofuran derivatives; ${ }^{\mathrm{c}}$ : tetrahydrofuran; ${ }^{\mathrm{d}}$ : inferences from ${ }^{1} \mathrm{H}$ NMR data from crude extracts.

preferences of six sap-sucking insects on Piperaceae species were analyzed and the stems were the tissue more heavily attacked (Table 2). The nymph and adult of $S$. sagata species were observed mainly on leaves of Piper solmsianum C. DC., $P$. regnellii C. DC. and $P$. tuberculatum Jacq; and also on fruits of $P$. cernuum Kunth. However, the presence of the nymph and adults does not always coincide with the fructification period of the $P$. cernuum Kunth. In the absence of the $P$. cernuum Kunth fruits, the insects appeared to migrate to the fruits of $P$. hispidum $\mathrm{Sw}$. and $P$. arboreum var. hirtellum Yunck.

\section{CONCLUSIONS}

The analysis for specificity between fourteen insects and about fifty Piperaceae species revealed a remarkable narrow feeding preference. The caterpillar species ( $Q$. u-lucida, $H$. hectorides, $H$. brasiliensis) were observed predominantly on lignan/neolignans-containing species such as $P$. solmsianum C. D C. and P. regnellii C. DC. In case of the beetles ( $N$. bipes, $N$. basilicus, N. versatilis, Chasmodia sp., C. fuscofasciatus) and sap-sucking Hemiptera species (M. foliata, S. sagata, E. meditabunda, A. reticulatum, Callocanophora sp., S. armata), the preferred Piper species were $P$. aduncum, $P$. gaudichaudianum which contained prenylated benzoic acids as major compounds.

However, the precise ecological role of lignan/neolignans and benzoic acid derivatives as phagostimulant or as products to be sequestered by insects for defense or as hormones still remained to be determined but such specificity could indicate co-adaptation or even co-evolution.

Our results corroborated the evolutionary history of plantsinsects, in which the majority of insects phytophagous are specifically associated with a limited number of vascular plants species (Harborne, 2001). Further investigations on the fate of secondary metabolites from each plant species during the digestive process of insects are on the way.

Acknowledgements. This work was funded by grants from FAPESP and CNPq. MJK is grateful to CNPq for research fellowship. CSR thanks FAPESP for providing a scholarship. We thank Dr. C. Costa, Dr. G. de M. Accacio and Dr. S. Ide for corroboration in the identifications of insect species. 


\section{REFERENCES}

Abrahamson, W. G. \& A. E. Weis. 1997. Evolutionary Ecology across Three Trophic Levels: Goldenrods, Gallmakers and Natural Enemies. Princeton Monographs in Population Biology. Princeton, NJ, USA: Princeton University Press. 456 p.

Alécio, A. C.; V. S. Bolzani; M. C. M. Young; M. J. Kato \& M. Furlan. 1998. Antifugal amides from Piper hispidum. Journal of Natural Products 61: 637-639.

Asprey, G. F. \& P. Thornton. 1954. Medicinal plants of Jamaica Part II. West Indian Medicinal Journal 3: 17-41.

Baldoqui, D. C.; M. J. Kato; A. J. Cavalheiro; V. da S. Bolzani; M. C. M. Young \& M. Furlan. 1999. A chromene and prenylated benzoic acid from Piper aduncum. Phytochemistry 51: 889-902.

Becerra, J. X. 1997. Insects on plants: macroevolutionary chemical trends in host use. Science 11: 253-256.

Benevides, P. J. C.; P. Sartorelli \& M. J. Kato. 1999. Phenypropanoids and neolignans from Piper regnellii. Phytochemistry 52: 339343.

Chauret, D. C.; C. B. Bernard; J. T. Arnason \& T. Durst. 1996. Insecticidal neolignans from Piper decurrens. Journal of Natural Products 59: $152-158$.

Danelutte, A. P.; M. B. Costantin; G. E. Delgado; R. Braz-Filho \& M. J. Kato. 2005. Divergence of secondary metabolism in cell suspension cultures and differentiated plants of Piper cernuum and $P$. crassinervium. Journal of the Brazilian Chemical Society 16(6B), 1425-1430.

Cronin, J. T. \& W. Abrahamson. 2001. Do parasitoids diversity in response to hosp-plant shifts by phytophagous insects? Ecological Entomology 26: 347-355.

Dyer, L. A.; C. D. Dodson \& J. Richards. 2004. Isolation, synthesis, and evolutionary ecology of Piper amides. Pages 117-139. In: Dyer, L.A. \& A.N. Palmer (eds.). Piper. A model genus for studies of evolution, chemical ecology, and trophic interactions. Kluwer Academic Publishers, Boston.

Figueiredo, R. A. \& M. Sazima. 2000. Pollination biology of Piperaceae species in southeastern Brazil. Annals of Botany 85: 455-460.

Fordyce, J. \& A. Agrawal. 2001. The role of plant trichomes and caterpillar group size on growth and defense of the pipevine swallowtail Battus philenor. Journal of Animal Ecology 70: 9971005 .

Glendinning, J. I. 2002. How do herbivorous insects cope with noxious secondary plant compounds in their diet? Entomologia Experimentalis et Applicata 104, 15-25.

Hartmann, T.; C. Theuring; T. Beuerle; N. Klewer; S. Schulz; M.S. Singer \& E.A. Bernays. 2005. Specific recognition, detoxification and metabolism of pyrrolizidine alkaloids by the polyphagous arctiid Estigmene acrea. Insect Biochemistry and Molecular Biology 35: 391-411.

Jaramillo, M. A.; P. S. Manos \& E. A. Zimmer. 2004. Phylogenetic relationships of the perianthless piperales: reconstructing the evolution of floral development. International Journal of Plant Science 165: 403-416.

Harborne, J. B. 2001. Twenty-five years of chemical ecology. Natural Products Report 18: 361-379.

Kato, M. J. \& M. Furlan. 2007. Chemistry and evolution of Piperaceae. Pure and Applied Chemistry 79: 529-538.
Kitamura, R. O. S.; P. Romoff; M. C. M. Young; M. J. Kato \& J. H. G. Lago. 2006. Chromenes from Peperomia serpens (Sw.) Loudon (Piperaceae). Phytochemistry 67: 2398-2402.

Lago, J. H. G.; C. S. Ramos; D.C.C. Casanova; A. A. Morandim; D. C. Bergamo; A. Cavalheiro; V. Bolzani; M. Furlan; E. Guimarães; M. Young \& M. J. Kato. 2004. Benzoic acid derivatives from Piper species and their fungitoxic activity against Cladosporium cladosporioides and C. sphaerospermum. Journal of Natural Products 67: 1783-1788.

Lawrence, J. F. 1991. Order Coleoptera, p. 144-658. In: Stehr, F. W. (ed.). Immature Insects Vol. 2. Kendal Publ., Dubuque, 975 p.

Lima, A. da C. 1953. Insetos do Brasil. Coleópteros, parte 2. Escola Nacional de Agronomia, Rio de Janeiro Vol. 8, 323 p.

Martins, R. C. C.; J. H.G. Lago; S. Albuquerque \& M. J. Kato. 2003. Trypanocidal tetrahydrofuran lignans from inflorescences of Piper solmsianum. Phytochemistry 64: 667-670.

Martins, R. C. C.; P. Latorre \& M. J. Kato. 2000. Phenypropanoids and tetrahydrofuran lignans from Piper solmsianum. Phytochemistry 55: 843-846.

Navickiene, H. M. D.; A. C. Alécio; M. J. Kato; V. S. Bolzani; M. C. Young; A. J. Cavalheiro \& M. Furlan. 2000. Antifungal amides from Piper hispidum and Piper tuberculatum. Phytochemistry 6: $621-626$.

Nishida, R. 2002. Sequestration of defensive substances from plants by Lepidoptera Annual Review of Entomology 47: 57-92.

Nora, I. \& W. Reis Filho. 1989. Danos causados por larvas de Curculionidae Pantomorus cervinus (Boheman, 1840), Pantomorus sp. e Naupactus sp. sobre plantas de macieira, In: Congresso Brasileiro de Entomologia, 12. Belo Horizonte, 453.

Ode, P. J. 2006. Plant chemistry and natural enemy fitness: effects on herbivore and natural enemy interactions. Annual Review of Entomology 51: 163-185.

Park, I. K.; G. S. Lee; S. Shin; J. Park \& J. Y. Ahn. 2002. Larvicidal activity of isobutylamides identified in Piper nigum fruits against three mosquito species. Journal of Agricultural and Food Chemistry 50: 1866-1870.

Parmar, V. S.; S. C. Jain; K. S. Bisht; R. Jain; P. Taneja; A. Jha; O. D. Tyagi; A. K. Prasad; J. Wengel; C. E. Olsen \& P. M. Boll. 1997. Phytochemistry of the genus Piper. Phytochemistry 47: 597673.

Paula, V. F.; L. C. D. Barbosa; A. J. Demuner; D. Piló-Veloso \& M. C. Picanço. 2000. Synthesis and activity of new amide derivative of piperine. Pest and Management Science 56:168-174.

Reis Filho, W. \& I. Nora. 1988. Naupactus: nova praga. Toda Fruta 25: 33-34.

Tyler, H.; K. S. Brown Jr. \& K. Wilson. 1992. Swallowtail Butterflies of the Americas. A Study in Biological Dynamics, Ecological Diversity, Biosystematics and Conservation. Scientific Publ., Gainsville, 376 p.

Ward, K. L.; A. Hachshaw \& R. T. Clarke. 2003. Do food-plant preferences of modern families of phytophagous insects and mites reflect past evolution with plants? Biological Journal of the Linnean Society 78: 51-83.

Yuncker, T. G. 1973. The Piperaceae of Brazil II: Piper - Group V; Ottonia; Pothomorphe; Sarcorhachis. Hoehnea 3: 29-284.

Yuncker, T. G. 1975. The Piperaceae of Brazil V: Index. Hoehnea 5: $123-145$. 